\title{
Employment and income support policies during the early phases of COVID-19: Lessons from the U.S., Denmark, and Taiwan
}

\author{
DChiao-Yu Yang ${ }^{1}$, Katharine Briar-Lawson ${ }^{1}$ and Jildyz Urbaeva ${ }^{1}$ \\ ${ }^{1}$ School of Social Welfare, University at Albany, State University of New York, NY, USA
}

Received 27 October 2020

Accepted for publication 12 December 2020

Published 18 December 2020

\begin{abstract}
As COVID-19 spread across the world in 2020, economic activities have been impacted, and unemployment has risen across many countries. The consequences have been particularly harmful to vulnerable populations such as women, racial minorities, or part-time workers. While many governments enacted employment and income support policies as a response to this economic crisis, there has been a lack of comparative and evaluative reviews of the policies. In this study, we contextualize some employment and income support policies during the early phases of COVID-19 from the U.S., Denmark, and Taiwan, aiming to enhance the understanding of such policies. We found that the U.S., being more aligned with a liberal welfare state regime, relied on more market mechanisms to address labor and employment issues. Denmark and Taiwan, being more aligned with a socialdemocratic welfare state, enacted more interventions in and redistributions outside of the market preventing furloughs, layoffs and mass unemployment. The human costs of unemployment and labor market hysteresis are addressed in light of these two different approaches and outcomes.
\end{abstract}

Keywords: unemployment hysteresis, income support, pandemic, liberal, social-democratic

In late December 2019, COVID-19, a transmittable disease caused by a new coronavirus, spread rapidly to almost every country in the world, impacting human lives and the global economy. As of December 2020, there were more than sixty million confirmed cases and more than 1.5 million deaths globally, with the numbers continuing to grow (John Hopkins University, 2020). The spread of the pandemic has affected people's economic activities, caused business failures, and has resulted in furloughs, layoffs and mass unemployment. According to the International Labour Organization [ILO] (2020a), the estimated decline in global working hours in the second quarter of 2020 was $17.3 \%$, relative to the fourth quarter of 2019 , and declined to $12.1 \%$ in the third quarter, with the U.S. experiencing a reduction in working hours of $19.8 \%$ in the third quarter of 2020.

To address some forms of employment and income supports during the early phases of COVID-19, many governments across the world designed and implemented various employment policies. However, given the rapidly changing pandemic conditions during the early phases of COVID-19, most policies were enacted in rapid succession, addressing only a few urgent issues at once, and policies across nations differed dramatically. Some nations implemented a more individualist policy approach such as short-term or one-time cash payments (e.g. stimulus checks for eligible taxpayers in the U.S.) while others offered guaranteed basic income (GBI) programs (e.g. Minimum Living Income, "IMV" in Spain) or universal basic income (UBI) programs that provide a regular, unconditional disbursement to individuals without means testing or work requirements (Van Parijs, 2013). A growing number of studies claim that a more univeralistic approach, such as UBI programs, address food security, mental health, may keep the most vulnerable in the population out of poverty (e.g. Johnson and Roberto, 2020; Ståhl and MacEachen, 2020). Few have compared and evaluated the employment and income support policies enacted across nations in response to the pandemic. As policy models and options can potentially be adopted for 
future economic crises, it is critical to evaluate and draw lessons from them.

In this study, employment and income support policies from the U.S., Denmark, and Taiwan were reviewed and evaluated. While COVID-19 ravaged the world alike, the economic pain played out differently between European countries, the U.S., and other regions of the world. Income support policies in the U.S., despite State-level differences, overall featured a significant expansion of unemployment insurance while most European countries prevented joblessness by nationalizing payrolls to subsidize wages, with Denmark serving as a robust model (Goodman, 2020; Goodman, Cohen, and Chaundler, 2020). In response to the COVID-19 crisis, most Asia and Pacific countries enacted extraordinary measures to strengthen their social protection systems (International Labour Organization, 2020c). Taiwan, a democratic and capitalist country from the region, was known for effective responses to COVID-19 based on its universalistic tradition regarding public health policies (Summers et al., 2020). An analysis of the employment and income support policies from the U.S., Denmark, and Taiwan should be able to draw meaningful implications for future employment and income policies.

This study consists of five main parts. First, we briefly describe the global pandemic and implications for the subsequent economic crises. Then we offer a synoptic description of the literature on unemployment hysteresis and income support policies during pandemics. We next explore related policies enacted in the U.S., Denmark, and Taiwan during the early phases of COVID-19, and classify these policies using liberal and social-democratic frames informed by Esping-Andersen's welfare state regime classification. Implications are drawn, looking especially at some of the benefits and costs to workers in different countries. We examine the extent to which policy responses involving income support measures, especially in the US, may foster conditions leading to unemployment hysteresis. Finally, limitations are discussed and recommendations are offered for policymakers and social work practitioners.

\section{The pandemic and unemployment hysteresis}

At the outset of a pandemic, most might think about it as a health issue with life or death consequences for those infected, while few might focus on its consequences for livelihood and income support. In fact, the twin adversities of health worries and threats to both income and employment together constitute, for some, a dual set of crises. The human costs of furloughs, lay-offs and mass unemployment bring with them their own severe consequences (Acs and Karpman, 2020;
Blustein et al., 2020; Fairlie, Couch and Xu, 2020). Moreover, the gravity of the pandemic and its individual and collective economic consequences may be compounded over time through a condition called hysteresis (Blanchard and Summers, 1986; Furuoka, 2017).

Often seen during recessions and depressions, hysteresis is present when the consequences of economic recessions are permanent. For example, some who are rendered jobless never return again to the labor market, in part, due to the irreversible human costs of their joblessness, including their skill obsolescence. Labor market rigidities such as decreased demand for employees may also cause hysteresis along with high rates of business foreclosures. Ball (2009) studied unemployment hysteresis in twenty developed countries, ranging from Western Europe, North America and the Antipodes, and Japan, and found that involuntary unemployment persisted despite policies to stimulate recovery and job generation. Hershbein and Stuart (2020) studied five national recessions in the U.S. (1973 - 1975; 1980 - 1982; 1990 - 1991; 2001; 2007 - 2009) and identified permanent declines in employment rates and economic activity after recessions. On average, a 5\% decrease in employment during those recessions led to a $6.2 \%$ decrease in employment within the following seven to nine years; areas that suffered larger employment losses experienced permanent reductions in employment and income (Hershbein and Stuart, 2020). Considering the effect of unemployment hysteresis, policy responses to threats to employment and income during a pandemic constitute critical foundations for the wellbeing of individuals, families, communities and nations as well as the GDP for the coming decade.

\section{Employment and income support policies during pandemics}

Common employment and income support policies enacted during pandemics include paid sick leave and income replacement and job security programs. Paid sick leave, which ensures infected employees stay at home, has been a policy found to be effective in reducing transmission of diseases in workplaces (Derigne, Stoddard-Dare and Quinn, 2016; Miraglia and Johns, 2016). Researchers have estimated that during an epidemic of influenza, $72 \%$ of transmissions in workplaces result from exposure to employees who show up to work sick (Kumar et al., 2013). Sick presenteeism occurs disproportionately among workers with financial difficulties and job insecurity. In particular, low-income, part-time, and female workers have higher rates of sick presenteeism because they are less likely to be paid when home sick than higherincome, full-time, and male workers (Lovell, 2004; Caverley, Cunningham and MacGregor, 2007; Miraglia and Johns, 
2016). Thus, some researchers have argued that guaranteed paid sick leave is necessary in the event of a public health emergency. With paid sick leave during a pandemic, workers will be more likely to stay home when ill, which will benefit the health of the whole workforce (Blake, Blendon and Viswanath, 2010; Drago and Miller, 2010).

Income replacement and job security programs are critical in a quarantine scenario where governments enact quarantine orders that prohibit public gatherings and request or even compel all but essential workers to stay at home to control the spread of the pandemic. Empirical studies have found that during quarantines, only a small proportion of workers, such as public servants, may have the opportunity to continue their work remotely; in contrast, workers in the private sector, small establishments, service or delivery industries, or other laborintensive jobs are less likely to work from home (Felstead et al., 2002; Hutchins et al., 2009). It is difficult for employees to comply with quarantine orders if they cannot work from home and their income or jobs are severely compromised (Rothstein and Coughlin, 2019; Holm, 2020). Such difficulties may be more prevalent among low-income workers who live near or below the poverty level, including many among racial or ethnic minority populations (e.g. African Americans and Latinos, in the U.S.) (Blendon et al., 2008; Hutchins, 2009). Thus, some researchers have argued that policy makers should recognize potential difficulties affecting quarantined individuals' willingness and ability to comply with quarantine orders and have recommended policies for some income replacement or job security to enhance or ensure compliance with quarantine policies (Rothstein and Coughlin, 2019).

\section{The liberal versus socio-democratic welfare state frame}

To compare and evaluate employment and income support policies during COVID-19 with a focus on how they address inequality, income and employment support, we used a liberal and social-democratic frame based on Esping-Andersen's (1990) typology of welfare state regimes. It has been claimed that welfare state structures are systematically related to labor market outcomes, and that cross-national differences in labor market behaviors can be attributed to the nature of welfare state regimes (Kolberg and Esping-Andersen, 1990). EspingAndersen's (1990) typology of welfare state regimes provide a useful frame for analyzing and comparing employment and income support policies during the pandemic.

\footnotetext{
${ }^{1}$ Some researchers have argued that "neoliberalism," compared to "a liberal state," more accurately reflects governmental policies based on ideas about the supremacy of free markets, the privatization of public services, deregulation and the efficiency of market forces (e.g. Giddens,
}

In the typology, the liberal model ${ }^{1}$ involves a minimum welfare state featuring modest means-tested assistance and strict entitlement rules targeting low-income populations, and encourages market solutions to social problems (e.g. by subsidizing private welfare schemes). The social-democratic model refers to a state that promotes high standards of social welfare rather than solely meeting minimal needs, and involves the decommodification of welfare services, reducing market-based access to welfare services, and socializing the costs of childcare, long-term care and related programs.

\section{The liberal approach: The U.S.}

During the early phase of COVID-19, responsive employment and income support policies in the U.S. included the Families First Coronavirus Response Act (FFCRA), Paycheck Protection Program (PPP), and increased unemployment benefits. Interventions in workplace safety were limited, leaving the norms of workplace safety to be decided by businesses and the price and supplies of personal protective equipment (PPE) subject to market demand.

FFCRA required employers to provide employees with two weeks of paid sick leave and up to ten weeks of paid family leave for circumstances related to the disease, with the plan to reimburse employers later with tax credits for the costs (U.S. Department of Labor, 2020a). This program allowed employees to stay home without having to worry as much about income losses during the pandemic. Ordinarily, there are no federal-level universal paid sick leave protections in the U.S. except for the Family and Medical Leave Act, requiring certain companies to provide unpaid sick leave (U.S. Department of Labor, 2020b).

PPP provided forgivable loans to employers as long as they, in turn, kept employees on the payroll and used at least $60 \%$ of the funds for payroll costs during a 24-week period. Forgiveness rates for these loans decreased if the full-time headcount declined, or if salaries and wages decreased. Initially, $75 \%$ of the funds were to be spent within eight weeks; soon regulations changed to require that only $60 \%$ be spent on the payroll within twenty-four weeks, providing greater flexibility for employers to qualify for loan forgiveness (Small Business Administration [SBA], 2020).

Both FFCRA and PPP included entitlement criteria, excluding a considerable portion of businesses and employees from these benefits. FFCRA exempted large businesses with more than 500 employees as well as small businesses that were

2014; Deeming, 2017). For consistency, we use the term "liberal" to reflect regimes in countries that embrace market mechanisms more than statelevel interventions. 
experiencing economic hardship (U.S. Department of Labor, 2020a). PPP covered small businesses with fewer than 500 employees, and certain independent contractors and non-profit entities (Small Business Administration, 2020). In effect, these policies relegated discretionary wage support to the market. While PPP aimed at assisting employees, employers served as mediators and distributors of the funds; FFCRA required employers to pay their employees during sick leave first and then apply to the government for tax reimbursement afterwards.

Other than enacting FFCRA and PPP, the U.S. also adjusted its unemployment benefits policy during the first phase of the pandemic (also known as the Federal Pandemic Unemployment Compensation program, FPUC). Ordinarily, the eligibility criteria for the benefits were defined at the state level and included becoming unemployed through no fault of one's own, meeting the state's requirements for wages earned or time worked during an established time period, being able and available to work, and actively seeking employment during each week they claim benefits. The amount and duration of unemployment benefits varied by state and were based on a percentage of an individual's earnings over a recent 52-week period, averaging $\$ 378$ per week in 2019 for 26 weeks in most states (U.S. Department of Labor, 2020c). During the early phases of COVID-19, the U.S. added $\$ 600$ weekly on top of the original state unemployment benefits and extended the compensation to independent contractors and other workers who were ordinarily ineligible for unemployment benefits. The FPUC program lasted for four months and ended July 31st, 2020 (U.S. Department of Labor, 2020c).

Overall, employment and income support policies enacted during the early phases of COVID-19 in the U.S. featured freemarket practices and minimized the state's intervention in the labor market, demonstrated less concern for strengthening employee-employer relationships, used strict entitlement criteria for eligibility, and gave employers more discretion in the provision of employment benefits (i.e. privatizing services and benefits). These all reflected practices consistent with the liberal welfare state regime. The management of unemployment beneficiaries is also aligned with the liberal welfare regime, which tends to implement supervisory or punitive means to manage the unemployed rather than to foster policies to strengthen employees' attachment to the labor market (Savelsberg, 2011; Soss, Fording and Schram, 2011). More specific attributes of the liberal regime approach include:

- Limited intervention in workplace safety and personal protective equipment markets;
- Income support programs with strict eligibility criteria;

- Employers as mediators and distributors of employment benefits;

- Indirect provision of benefits (e.g. tax reimbursement);

- $\quad$ Manipulating unemployment benefits.

\section{The social-democratic approach: Denmark and Taiwan}

During the first phase of COVID-19, Denmark was among the first European countries to close schools and urge employers either to send employees home or to take precautionary measures such as fostering more shifts, undertaking risk assessments, and providing hand sanitizers to ensure workplace safety (Copenhagen Capacity, 2020). There was a temporary amendment enabling employers to postpone employees' holidays to facilitate changed work hours, as well as to require strict regulations to maintain safe working environments (e.g. to disclose personal information) (Danish Health Authority, 2020).

Taiwan implemented a timely intervention in the market to control the spread of the disease. During the early phase of COVID-19, the Taiwanese government negotiated with domestic manufacturers to furnish surgical masks and gowns, installed its own production lines, mobilized soldiers to aid in their production, and expropriated and allocated PPE to local healthcare institutions and retailers (Wang, $\mathrm{Ng}$ and Brook, 2020). PPE was rationed at fixed prices so that everyone in Taiwan was able to purchase the PPE with their identification documents (e.g. National Health Insurance cards or passports).

Both Denmark and Taiwan provided universal coverage for paid sick leave and income support programs during this first phase of COVID-19. Ordinarily, Danish employees enjoyed thirty days of paid sick leave per year paid by the employers; those not eligible for the paid sick leave would have sickness benefits covered by local authorities for up to twenty-two weeks within nine calendar months (European Commission, 2020). Due to the impact of the pandemic on businesses, the Danish government agreed to cover the costs if the sick leave was related to COVID-19 (Copenhagen Capacity, 2020). Before COVID-19 hit, Taiwan employees were already guaranteed thirty days of paid sick leave a year at half their general salary, and at least at a minimum monthly wage regardless of their working hours (Ministry of Labor, 2019). During the early phase of COVID-19, some citizens had to stay quarantined at home for fourteen days due to their 
travel or contact histories; however, their leave did not qualify for paid sick leave. Thus, the Taiwanese government provided quarantine compensation at approximately US $\$ 35$ per day for the duration for those required to stay at home (Ministry of Health and Welfare, 2020). In this way, employees did not experience severe income loss and could comply with the quarantine orders. Such policies in Denmark and Taiwan protected employees from dangerous working environments and enabled certain employees to stay at home with their income partially supported.

To prevent mass layoffs following the lockdown order, the Danish government introduced a four-month (March $9^{\text {th }}$ to July $8^{\text {th }}$ ) universal wage compensation scheme that paid $75 \%$ of full-time employees' salaries and $90 \%$ of hourly workers' wages. These wage subsidies were paid by the Danish government directly to employees themselves for businesses across all industries that were experiencing financial difficulty (Ministry of Industry, 2020a; Ministry of Industry, 2020b). The universal income support package maintained and helped to stabilize workforces for companies and ensured that most employees maintained their job and income at least during the first phase of the public health and economic crisis.

Taiwan did not experience a mass lockdown during the emergence of COVID-19. Yet, the government agreed to pay $50 \%$ of the amount of any wage reduction for furloughed employees for up to six months and provide income support at $42 \%$ of the minimum salary for self-employed workers for three months (Executive Yuan, 2020). The Taiwanese government also introduced a three-month online training project to pay employees $70 \%$ of their original salary for up to 120 hours a month if they attended specific online training programs during their reduced working hours (Executive Yuan, 2020).

Unemployment programs in social-democratic regimes have historically acted as an incentive for employment instead of a net income allowance; this approach did not change during the pandemic. Neither Denmark nor Taiwan adjusted their unemployment benefits during COVID-19. Denmark exempted unemployment beneficiaries from having to apply for one to two jobs per week during the pandemic and added four additional months to the three-year benefit duration (March $1^{\text {st }}$ to June $\left.30^{\text {th }}, 2020\right)$ (Copenhagen Capacity, 2020). The Taiwanese government arranged for more than 13,000 part-time jobs in the public sector for part-time workers, a relatively vulnerable population in the labor market during an economic crisis, aiming to assist disadvantaged employees in returning to the job market (Executive Yuan, 2020).

Overall, the employment and income support policies in Denmark and Taiwan were more aligned with the social- democratic regime, featuring strong interventionist, universalist, and institutionalized redistribution based on a commitment to full employment (Esping-Andersen, 1990). Such income support programs do not exclude recipients by their industry, or scale of companies, and most income compensation was delivered through paychecks sent directly to the employees. Specific attributes of the social-democratic regime include:

- Intervention in maintaining workplace safety and allocating personal protective equipment;

- Universal coverage of income support programs;

- Employees as direct recipients of income and employment benefits;

- Direct provision of employment benefits (e.g. in cash);

- Allocating work opportunities for vulnerable workers.

\section{Discussion}

The above analysis underscores the policy discrepancies between the U.S., Denmark, and Taiwan involving the economic crises caused by COVID-19, which reflects Kolberg and Esping-Andersen's (1990) theory that regards states' interventions in the market as indicators of decommodification at work. By passing off the critical evaluation and redistribution tasks to market mechanisms, the U.S. may have avoided tough decisions about the allocation of scarce resources and saved considerable time and human resources (Morgan and Campbell, 2011). On the other hand, Denmark and Taiwan, with a commitment to full employment and to addressing inequality in unemployment during the outbreak of the pandemic, may have been more successful in maintaining employment and livelihoods and promoting the well-being of different groups of workers.

\subsection{Unemployment: human costs and hysteresis risk factors}

In the severe pandemic scenario of COVID-19, the demand for wage and employment support was high, and many companies were less likely to guarantee sufficient wages and benefits. The liberal approach's reliance on the market mechanism of picking winners and losers, seen in the U.S., excluded many people from employment and livelihood stability, healthcare coverage and related support in the labor market. For example, the exemptions in FFCRA left as many as $85 \%$ of essential workers in grocery, pharmacy, and general merchandise unprotected during COVID-19 (Schneider and Harknett, 2020). Some of these unprotected workers may have 
had no choice but to leave the labor market when they had health concerns or health care responsibilities during the pandemic.

Meanwhile, the effects of raised and extended unemployment benefits remained unclear. Some empirical studies found that raising unemployment benefits has no significant effect on enhancing employment or the job search (e.g. Abraham and Houseman, 2014; Boone et al., 2016). Other researchers even argued that increased unemployment benefits would reduce the intensity of job search (e.g. Daly et al., 2012; Wang, Ng and Brook, 2020). Moreover, such an approach of placing unemployed individuals in the position of welfare recipients or dependents could have discouraged workers from seeking appropriate, stable and safe jobs as well as increase their disadvantage, vulnerability, and social exclusion in the long run (Savelsberg, 2011). In effect, unemployment rates in the U.S. rose dramatically from $4 \%$ in January 2020 to reach a peak of $14.4 \%$ in April. Although most States in the U.S. ceased lockdowns and re-opened their economy by the end of May 2020 (NASHP, 2020), unemployment rates did not bounce back subsequently, and declined only slightly to $10.5 \%$ in $\mathrm{July}^{2}$ (see Figure 1).

The significant increase in unemployment rates signals a rise in the often-high human costs associated with layoffs that may not be mediated by residual welfare state provisions. For example, in March 2020, the U.S. approved a means-tested, one-time stimulus check to eligible taxpayers; however, the fund did not provide a lasting benefit as several million in the United States still were forced to draw unemployment benefits (Johnson and Roberto, 2020). With layoffs leading to workers' ruptured attachment to their employer and the labor market itself, unemployment hysteresis, in which the jobless never return to work, may take over, resulting in more irreversible harms to the worker, family, labor market and society. As most health benefits are tied to employment in the U.S., losing a job may mean losing health insurance. Job losses between February and July of 2020 have resulted in approximately 6.2 million laid-off workers being uninsured in the U.S. (Bivens and Zipperer, 2020), significantly higher than any annual increase before (Dorn, 2020).

\footnotetext{
2 The CPS unemployment data of the U.S. from March to June 2020 could have been underestimated. According to the U.S. Bureau of Labor Statistics, workers who were "furloughed due to temporary, coronavirus-related business closures" during the pandemic should be classified as "unemployed on temporary layoff." However, a considerable number of such workers have been misclassified as being "employed but absent from work due to other reasons," which does not count in the unemployment rate. The real
}

Figure 1. Unemployment rates in the U.S., Denmark, and Taiwan from January to July 2020

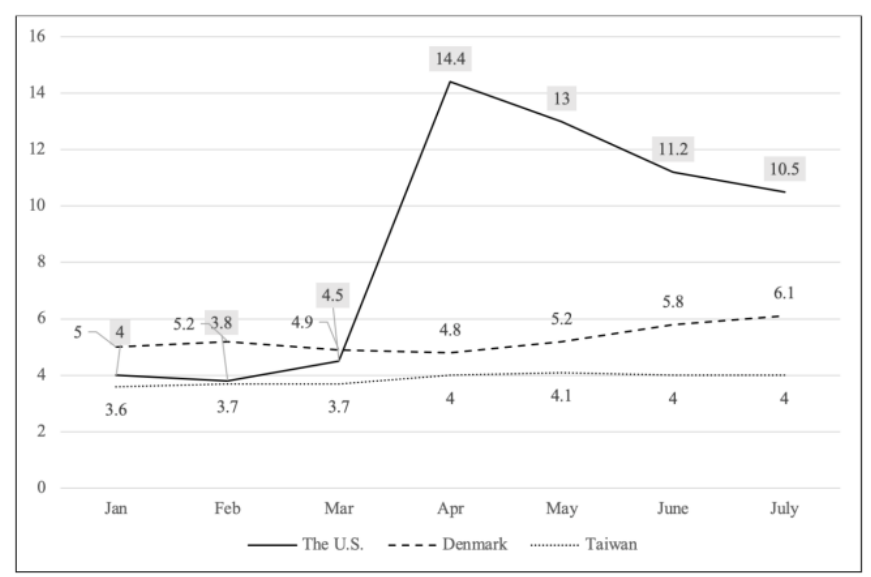

Source: International Labour Organization (2020b), available at: https://ilostat.ilo.org/data/

For some, unemployment is a human disaster that involves the toll of financial insecurity and the psychological impact of joblessness as well as the loss of home, family, and health. This is because the jobless often cannot pay rent, or cover food or auto costs. For some, the stress affects their health, causing rises in substance use, and cardiovascular and related diseases (Browning and Heinesen, 2012). A spell of unemployment, especially if it is long term, such as six months or more, may begin a demise syndrome in some. Depression, followed by family conflict, and divorce (Charles and Stephens, 2004) may lead to self-medicating behaviors and even suicidal thoughts or actions (Briar-Lawson, 1988; Classen and Dunn, 2012). Some may die prematurely (Omay, Ozcan and Shahbaz, 2020). In fact, it has been found that death rates increase by $50 \%$ to $100 \%$ during prolonged unemployment (Sullivan and von Wachter, 2009). The long-run reduction in income and increase in poverty is also likely to reduce children's economic mobility (Stuart, 2019).

When a social-democratic regime strategy promotes a more robust set of policy responses that constitutes labor market investments in protecting workers with minimal layoffs, most employees can stay at home when ill or work flexible hours during a pandemic without losing their jobs or income, employers receive support to keep their employees on payrolls, and more employees can stay in the labor market.

unemployment rate in the U.S. in April and May 2020 could have been about three percentage points higher than reported and in June 2020 could have been one percentage point higher than reported. See https://www.bls.gov/news.release/pdf/empsit.pdf for more detailed information. 
Thus, mass unemployment can be prevented, and the human costs of joblessness are averted, including hysteresis. Such labor market investments are also more likely to result in a faster and safer restart of the economy and businesses after the early phases of a pandemic such as COVID-19. Employers have their workforces intact and do not have to start rebuilding, unlike conditions often seen in the liberal regime. Consistent with our analysis, unemployment rates in Denmark and Taiwan remained relatively stable during the same period (International Labour Organization, 2020b) (see Figure 1).

\subsection{Addressing inequality in unemployment}

In addressing inequality, both Denmark and Taiwan already had in place guaranteed, paid sick leave programs before the outbreak of COVID-19 and fostered some institutional redistribution of jobs and wage support outside of the market to address disparities during COVID-19. Denmark offered a higher percentage of wage support for part-time workers, and Taiwan preserved more work opportunities for part-time workers. These investments set aside funds for identified vulnerable populations, which may have addressed the inequality in unemployment among different groups of workers. Additionally, such approaches were consistent with the decommodification of labor. In the social-democratic regime this includes a politically organized system of collective goods production (e.g. welfare state employment, PPE) and programs that offer workers a choice about whether to work or pursue alternative activities (Kolberg and EspingAndersen, 1990). Under this decommodified labor approach, the concept of efficiency is less emphasized, and employees enjoy rights even within the contract of employment, as their needs in their private lives are prioritized (Kolberg and Esping-Andersen, 1990).

On the other hand, the deregulation of business practices in the U.S. may have increased inequalities through challenging the basic fabric of trust and cooperation involving social partnerships and worker-employer relations (EspingAndersen, 2006). Relegating the provision of PPE products to market mechanisms, for example, has resulted in stockpiling and price gouging of products, and vicious competition among state governments and healthcare institutions for PPE products (e.g. U.S. Department of Justice, 2020) and, in turn, has deprived populations by giving them less power over workplace safety, job and income stability (Communications
Workers of America, 2020; Thompson, 2020). Relegating the provision of income support to employers and fostering employers' discretion in managing employees' welfare very likely generated conflicts of interest between employers and employees, in which vulnerable employees (e.g. females, those of color and part-time workers) were more likely to lose their jobs and income support in the process of negotiation.

In effect, there was a significant gender and racial/ethnic gap in the increase in unemployment rates during the first phases of COVID-19 in the U.S. While unemployment rates of U.S. males increased by 5.5 percentage points between January and July 2020, unemployment rates of U.S. females increased by 7.6 percentage points. The difference between genders exceeded that seen in Denmark or Taiwan (International Labour Organization, 2020b). Among all racial and ethnic groups in the U.S., Asians had a relatively high unemployment rate increase, at nine percentage points, followed by Blacks/African American and Hispanics or Latinos, both at 8.6 percentage points. Particularly, the unemployment rates of Blacks/African Americans remained the highest across the period. In addition, part-time workers experienced an unemployment rate increase at 8.5 percentage points, which was much higher than the increase among fulltime workers, at 6.3 percentage points (U.S. Bureau of Labor Statistics, 2020) (see Table 1).

These statistics indicated that, although all employees experienced a higher risk of unemployment during the first phases of COVID-19, some populations such as females, those of color and part-time workers were more vulnerable amidst the crisis. Particularly, part-time workers have been a population experiencing severe "in-work poverty" (Horemans, Marx and Nolan, 2016), comprising disproportionately race and gender minorities, immigrants, and single mothers (Lovell, 2004; Rothstein and Coughlin, 2019). In the U.S., $27.99 \%$ of employed females work parttime, compared to $16.46 \%$ part-time employed males; in Denmark, $53.59 \%$ of employed females work part-time, compared to $33.43 \%$ part-time employed males (World Economic Forum, 2019). ${ }^{3}$ Hence, policies that bolster work and income support for part-time workers could effectively reduce the disparity in unemployment rates between males and females including those of color, while the absence of such policies could increase the disparities.

\footnotetext{
${ }^{3}$ Related statistics of Taiwan are unavailable.
} 
Table 1. Unemployment rate increase in the U.S., Denmark, and Taiwan from January to July 2020

\begin{tabular}{|c|c|c|c|c|c|c|c|c|}
\hline & \multicolumn{7}{|c|}{ Unemployment Rates (\%) } & \multirow{2}{*}{$\begin{array}{c}\text { Changes in } \\
\text { Unemployment } \\
\text { Rates (\% points) }\end{array}$} \\
\hline & Jan & Feb & Mar & Apr & May & June & July & \\
\hline US & 4 & 3.8 & 4.5 & 14.4 & 13 & 11.2 & 10.5 & 6.5 \\
\hline Male & 4.2 & 4.1 & 4.8 & 13.3 & 11.9 & 10.5 & 9.7 & 5.5 \\
\hline Female & 3.7 & 3.4 & 4.2 & 15.7 & 14.3 & 12 & 11.3 & 7.6 \\
\hline White & 3.1 & 3.1 & 4 & 14.2 & 12.4 & 10.1 & 9.2 & 6.1 \\
\hline $\begin{array}{c}\text { Black/African } \\
\text { American }\end{array}$ & 6.0 & 5.8 & 6.7 & 16.7 & 16.8 & 15.4 & 14.6 & 8.6 \\
\hline Asian & 3.0 & 2.5 & 4.1 & 14.5 & 15.0 & 13.8 & 12 & 9 \\
\hline Hispanic or Latino & 4.3 & 4.4 & 6.0 & 18.9 & 17.6 & 14.5 & 12.9 & 8.6 \\
\hline Full-time Worker & 3.5 & 3.5 & 4.1 & 12.9 & 12.0 & 10.4 & 9.8 & 6.3 \\
\hline Part-time Worker & 4.1 & 3.7 & 6.1 & 24.5 & 19.7 & 14.7 & 12.6 & 8.5 \\
\hline Denmark & 5.0 & 5.2 & 4.9 & 4.9 & 5.3 & 5.7 & 6.1 & 1.1 \\
\hline Male & 5.0 & 5.0 & 4.9 & 4.6 & 4.9 & 5.2 & 5.9 & .9 \\
\hline Female & 5.0 & 5.4 & 4.9 & 5.2 & 5.7 & 6.3 & 6.2 & 1.2 \\
\hline Taiwan & 3.6 & 3.7 & 3.7 & 4.0 & 4.1 & 4.0 & 4 & .4 \\
\hline Male & 3.7 & 3.8 & 3.8 & 4.1 & 4.1 & 4.0 & 4 & .3 \\
\hline Female & 3.6 & 3.6 & 3.6 & 3.9 & 4.0 & 3.9 & 4 & .4 \\
\hline
\end{tabular}

Sources: (1) International Labour Organization (2020b), available at: https://ilostat.ilo.org/data/ and (2) U.S. Bureau of Labor Statistics (2020), available at: https://www.bls.gov/news.release/empsit.t10.htm

\section{Implications and recommendations}

This study of the differential policy responses to the economic crises during the early phases of the pandemic reveals profoundly different outcomes for populations in the U.S. versus Taiwan and Denmark. Drawing lessons from these countries, the study derives some recommendations for policy makers and social work practitioners.

7.1 Welfare policy programs during a universal economic crisis should exceed the liberal welfare state norm

This comparative analysis suggests that labor, income and welfare support programs enacted during a universal economic crisis such as that brought about by a pandemic should not be subjected to liberal regime policy. The limitations of the liberal welfare state regime, including its slowness and weakness in public health intervention, are evident as a strong recession emerged during the first phase of COVID-19. Thus, during a pandemic, governments should not hesitate to intervene in the market for health concerns to reduce transmission in workplaces and to prevent employees from severe job or income loss. This could include the allocation and distribution of PPE, travel history tracing, sanitizing workplaces, compulsory temperature checks or testing, and fostering more mandatory mask use. Currently, such interventionist regulations are more prevalent in Asian countries where collectivism is more accepted, and individuals are more willing to endure inconvenience for the well-being of society.

Further, more social-democratic or universalist employment and income support programs should be 
considered amidst a global economic crisis. During the early phase of COVID-19, policies in the U.S. were more exclusive, using more entitlement criteria or exemptions (e.g. the scale of businesses) to define deserving "recipients." Such an exclusive approach could result in specific problems (e.g. sick presenteeism; transmission in workplaces; layoffs) occurring disproportionately among particular groups and yielding a higher unemployment rate. In contrast, employment policies in Denmark and Taiwan, such as universal coverage of healthcare services, paid sick leave, and income support programs were more inclusive and featured redistribution, addressing the inequities vulnerable populations faced.

Policies are social problem-solving tools. They are both remedial and preventive. In effect, our study suggests that the social-democratic approach, with an investment in stabilizing workers and their wage support, is preventive compared to the investment in unemployment benefits, seen in the liberal welfare state model. As Denmark and Taiwan's policies appeared to be more effective in maintaining employment during COVID-19, it is suggested that policymakers from a liberal regime consider implementing a more socialdemocratic approach to policies (e.g. an emergency UBI program, as proposed by Ståhl and MacEachen, 2020). Such preventive-oriented investments could avert some of the human costs of an economic recession, including hysteresis among the jobless, expected in the U.S. Moreover, UBI could help support small businesses and economic activity. However, UBI is not a substitute for jobs, decent wages and an array of other social protections.

\subsection{Social work as a profession and social work practitioners should advocate for vulnerable groups of workers and address the potential effects of unemployment hysteresis}

The current study calls for concern over the vulnerable status of groups of workers during an economic crisis such as a pandemic; these include women, racial and ethnic minorities, and part-time workers. For example, mothers are normally more likely than fathers to become the primary caregiver of a sick family member, and family illnesses are more likely to lead to job loss and income reduction for women than for men. It is essential that social welfare programs address such inequality and be flexible in implementation to address urgent and unique circumstances. For example, health services such as testing and treatment can be preserved for individuals and families who experienced job loss or became uninsured during a pandemic.

Also, practitioners should be prepared as unemployment is a bellwether for future livelihood and health consequences.
Unemployment is used globally not only as a social indicator of labor market performance but also to gauge human wellbeing. These different unemployment data across nations and populations foreshadow longer-term human despair versus relative wellbeing. When the harms from joblessness are irreversible, and hysteresis may have set in, the currently unemployed may never return to the labor market as the human costs may persist into the future, long after the pandemic and economic disaster have ended. Hence, our study suggests that more resources should be devoted to addressing potential unemployment hysteresis. For example, income support programs could be implemented to reduce poverty, and mental health services or trauma intervention could be provided to enhance resilience among the unemployed populations. Wage supports and job creation programs, targeting the long term jobless, are also key in addressing the human costs of unemployment and hysteresis.

Social workers often address the human consequences of joblessness. Treatment for depression, marital conflict and domestic violence, child abuse and neglect, addictions, are key areas for social work interventions. More proactive social work leadership and advocacy are needed in policy and program development for social protections that prevent joblessness, income loss, unemployment hysteresis and the related human costs. Lessons learned from Denmark and Taiwan suggest that social workers need to press for equitable and guaranteed employment and income support programs.

\section{Limitations}

The study discussed only employment and income support policies, along with attention to health protections, such as PPE, and excluded other welfare policies that may have had a critical impact on unemployment during the pandemic (e.g. child care and child welfare policies, health insurance systems, active labor market programs, education policies and home schooling of children). The study was limited to the examination of policies in the U.S., Taiwan, and Denmark, all democratic, capitalist, and industrialized countries. Thus, the findings may not apply to other countries. Finally, this analysis has focused on the earliest phases of COVID-19. Given the uncertainty as to when the virus may become less of a threat, and with more outbreaks expected in the months ahead, these three nations may enact more welfare policies shortly. Thus, the study constitutes an early snapshot of pandemic and related economic responses. Future studies could include more aspects of social policies from countries with different welfare state orientations to contextualize their differential impacts and outcomes. 


\section{References}

Abraham, K.G. and Houseman, S.N. (2014) 'Short-time compensation as a tool to mitigate job loss? Evidence on the US experience during the recent recession', Industrial Relations: A Journal of Economy and Society, 53(4), pp. 543-567. Doi: 10.17848/wp12-181

Acs, G. and Karpman, M. (2020) Employment, income, and unemployment insurance during the COVID-19 Pandemic. Available at: https://www.urban.org/sites/default/files/publication/10 2485/employment-income-and-unemploymentinsurance-during-the-covid-19-pandemic.pdf (Accessed: 13 September 2020).

Ball, L.M. (2009) 'Hysteresis in unemployment: old and new evidence', National Bureau of Economic Research (No. w14818). Doi: 10.3386/w14818

Bivens, J. and Zipperer, B. (2020) Health insurance and the COVID-19 shock: What we know so far about health insurance losses and what it means for policy. Available at: https://www.epi.org/publication/health-insuranceand-the-covid-19-shock/ (Accessed 26 August 2020).

Blake, K.D., Blendon, R.J. and Viswanath, K. (2010) 'Employment and compliance with pandemic influenza mitigation recommendations', Emerging Infectious Diseases, 16(2), pp. 212-218. Doi: 10.3201/eid1602.090638

Blanchard, O. and Summers, L. (1986) 'Hysteresis and the European unemployment problem', NBER Macroeconomics Annual, 1, pp. 15-78. Doi: $10.1086 / 654013$

Blendon, R.J., Koonin, L.M., Benson, J.M., Cetron, M.S., Pollard, W.E., Mitchell, E.W., Weldon, K.J. and Herrmann, M.J. (2008) 'Public response to community mitigation measures for pandemic influenza', Emerging Infectious Diseases, 14(5), pp. 778-786. Doi: 10.3201/eid1405.071437

Blustein, D.L., Duffy, R., Ferreira, J.A., Cohen-Scali, V., Cinamon, R.G. and Allan, B.A. (2020) 'Unemployment in the time of COVID-19: A research agenda', Journal of Vocational Behavior, $119 . \quad$ Doi: 10.1016/j.jvb.2020.103436

Boone, C., Dube, A., Goodman, L. and Kaplan, E. (2016) 'Unemployment insurance generosity and aggregate employment', Institute of Labor Economics (IZA) Discussion Papers, $\quad$ No. 10439. http://hdl.handle.net/10419/161062

Briar-Lawson, K. (1988) Social work and the unemployed. National Association of Social Workers.

Browning, M. and Heinesen, E. (2012) 'Effect of job loss due to plant closure on mortality and hospitalization',
Journal of Health Economics, 31(4), pp. 599-616. Doi: 10.1016/j.jhealeco.2012.03.001

Caverley, N., Cunningham, J.B. and MacGregor, J.N. (2007) 'Sickness presenteeism, sickness absenteeism, and health following restructuring in a public service organization', Journal of Management Studies, 44(2), pp. 304-319. Doi: 10.1111/j.1467-6486.2007.00690.x

Charles, K.K. and Stephens, Jr, M. (2004) 'Job displacement, disability, and divorce' Journal of Labor Economics, 22(2), pp. 489-522. Doi: 10.1086/381258

Classen, T.J. and Dunn, R.A. (2012) 'The effect of job loss and unemployment duration on suicide risk in the United States: A new look using mass-layoffs and unemployment duration', Health Economics, 21(3), 338350. Doi: 10.1002/hec.1719

Communications Workers of America (2020) We need OSHA to protect workers during the COVID-19 outbreak. Available at: https://cwa-union.org/news/enewsletter/2020-04-09 (Accessed: 9 April 2020).

Copenhagen Capacity (2020) Extended: Relief packages. Available at: https://www.copcap.com/covid19extension-of-relief-packages (Accessed: 18 July 2020).

Daly, M.C., Hobijn, B., Şahin, A. and Valletta, R.G. (2012) 'A search and matching approach to labor markets: Did the natural rate of unemployment rise?', Journal of Economic Perspectives, 26(3), pp. 3-26. Doi: 10.1257/jep.26.3.3

Danish Health Authority (2020) Frequently asked questions about COVID-19. Available at: https://www.sst.dk/da/corona/FAQ (Accessed: 4 July 2020).

Deeming, C. (2017) 'The lost and the new 'liberal world' of welfare capitalism: A critical assessment of Gøsta Esping-Andersen's the three worlds of welfare capitalism a quarter century later', Social Policy and Society, 16(3), pp. 405-422. Doi: 10.1017/S1474746415000676

Derigne, L., Stoddard-Dare, P. and Quinn, L. (2016) 'Workers without paid sick leave less likely to take time off for illness or injury compared to those with paid sick leave', Health Affairs, 35(3), pp. 520-527. Doi: 10.1377/hlthaff.2015.0965

Dorn, S. (2020) The COVID-19 pandemic and resulting economic crash have caused the greatest health insurance losses in American history. Available at: https://www.familiesusa.org/resources/the-covid-19pandemic-and-resulting-economic-crash-have-causedthe-greatest-health-insurance-losses-in-americanhistory/ (Accessed 28 August 2020).

Drago, R. and Miller, K. (2010) Sick at work: Infected employees in the workplace during the H1N1 pandemic. Available https://www.henrythehand.com/wpcontent/uploads/2015/01/Sick-at-Work-BriefingPaper.pdf (Accessed: 4 July 2020). 
Esping-Andersen G. (1990) The three worlds of welfare capitalism. Polity Press.

Esping-Andersen, G. (2006) 'A welfare state for the twentyfirst century' in Pierson, C. and Castles, F.G. (eds.) The welfare state reader. Cambridge: Polity, pp. 434-454.

European Commission (2020) Denmark-sickness benefit. Available

at: https://ec.europa.eu/social/main.jsp?catId=1107\&langId $=$ en\&intPageId=4489 (Accessed: 4 July 2020).

Executive Yuan (2020) Special act on COVID-19 prevention, relief and restoration. Available at: https://www.ey.gov.tw/Page/5A8A0CB5B41DA11E/ad 3f40f1-9a79-47f6-8a2b-0883ba2c0b05 (Accessed: 28 Aug 2020).

Fairlie, R.W., Couch, K. and Xu, H. (2020) 'The impacts of covid-19 on minority unemployment: First evidence from April 2020 cps microdata', National Bureau of Economic Research. Doi: 10.3386/w27246

Felstead, A., Jewson, N., Phizacklea, A. and Walters, S. (2002) 'Opportunities to work at home in the context of work-life balance', Human Resource Management Journal, 12(1), pp. 54-76. Doi: 10.1111/j.17488583.2002.tb00057.x

Furuoka, F. (2017) 'A new approach to testing unemployment hysteresis', Empirical economics, 53(3), pp. 1253-1280. Doi: 10.1007/s00181-016-1164-7

Giddens, A. (2014) Studies in social and political theory (RLE Social Theory). London: Routledge.

Goodman, P.S. (2020) The Nordic Way to Economic Rescue. Available at: https://www.nytimes.com/2020/03/28/business/nordicway-economic-rescue-virus.html (Accessed: 9 July 2020).

Goodman, P.S., Cohen, P. and Chaundler, R. (2020) European Workers Draw Paychecks. American Workers Scrounge for Food. Available at: https://www.nytimes.com/2020/07/03/business/econom y/europe-us-jobless-coronavirus.html (Accessed: 9 July 2020).

Hershbein, B. and Stuart, B.A. (2020) 'Recessions and local labor market hysteresis', Upjohn Institute for Employment Research. Doi: 10.17848/wp20-325

Holm, S. (2020) 'A general approach to compensation for losses incurred due to public health interventions in the infectious disease context', Monash Bioethics Review, online first. Doi: 10.1007/s40592-020-00104-2

Horemans, J., Marx, I. and Nolan, B. (2016) 'Hanging in, but only just: part-time employment and in-work poverty throughout the crisis', IZA Journal of European Labor Studies, 5(1), p. 5. Doi: 10.1186/s40174-016-0053-6

Hutchins, S.S., Fiscella, K., Levine, R.S., Ompad, D.C. and Mcdonald, M. (2009) 'Protection of Racial/Ethnic Minority Populations During an Influenza Pandemic',
American Journal of Public Health, 99(S2), pp. 261-270. Doi: 10.2105/ajph.2009.161505

International Labour Organization (2020a) COVID-19 and the world of work. Sixth edition. Available at: https://www.ilo.org/global/topics/coronavirus/lang-en/index.htm (Accessed: 30 September 2020).

International Labour Organization (2020b) ILOSTAT database: Unemployment rate by sex and age (\%) monthly. Available at: https://ilostat.ilo.org/data/ (Accessed: 30 September 2020).

International Labour Organization (2020c) Social protection responses to COVID-19 in Asia and the Pacific: The story so far and future considerations. Available

at: https://www.ilo.org/asia/publications/WCMS_753550/la ng--en/index.htm (Accessed: 22 August 2020).

John Hopkins University (2020) COVID-19 Global Dashboard. Available at: https://coronavirus.jhu.edu/map.html (Accessed: 30 September 2020).

Johnson, A.F. and Roberto, K.J. (2020) 'The COVID-19 pandemic: Time for a universal basic income?', Public Administration and Development, 40(4), pp. 232-235. Doi: 10.1002/pad.1891

Kolberg, J.E. and Esping-Andersen, G. (1990) 'Welfare states and employment regimes', International Journal of Sociology, 21(1), pp. 3-36. Doi: 10.1080/15579336.1990.11769998

Kumar, S., Grefenstette, J.J., Galloway, D., Albert, S.M. and Burke, D.S. (2013) 'Policies to reduce influenza in the workplace: Impact assessments using an agent-based model', American Journal of Public Health, 103(8), pp. 1406-1411. Doi: 10.2105/ajph.2013.301269

Lovell, V. (2004) 'No time to be sick: Why everyone suffers when workers don't have paid sick leave', PsycEXTRA Dataset. Doi: 10.1037/e572072011-001

Ministry of Health and Welfare (2020) Compensation for quarantined individuals and caregivers. Available at: https://topics.mohw.gov.tw/COVID19/cp-4715-52167205.html (Accessed: 21 July 2020).

Ministry of Industry (2020a) COVID-19: Tripartite agreement to help workers. Available at: https://em.dk/nyhedsarkiv/2020/marts/covid-19trepartsaftale-skal-hjaelpe-loenmodtagere/ (Accessed: 16 July 2020).

Ministry of Industry (2020b) COVID-19: Tripartite agreement on temporary pay compensation extended by one month. Available at: https://em.dk/nyhedsarkiv/2020/april/covid-19trepartsaftale-om-midlertidig-loenkompensationforlaenget-med-en-maaned/ (Accessed: 16 July 2020).

Ministry of Labor (2019) Regulations of leave-taking of workers.

Available 
https://law.moj.gov.tw/ENG/LawClass/LawAll.aspx?pc ode $=$ N0030006 (Accessed: 12 August 2020).

Miraglia, M. and Johns, G. (2016) 'Going to work ill: A meta-analysis of the correlates of presenteeism and a dual-path model', Journal of Occupational Health Psychology, 21(3), pp. 261-283. Doi: 10.1037/ocp0000015

Morgan, K.J. and Campbell, A.L. (2011) The delegated welfare state: Medicare, markets, and the governance of social policy. Oxford: Oxford University Press.

National Academy for State Health Policy [NASHP] (2020) Chart: Each State's COVID-19 Reopening and Reclosing Plans and Mask Requirements. Available at: https://www.nashp.org/governors-prioritize-health-forall/ (Accessed: 8 December 2020).

Omay, T., Ozcan, B. and Shahbaz, M. (2020) 'Testing the hysteresis effect in the US state-level unemployment series', Journal of Applied Economics, 23(1), pp. 329348. Doi: 10.1080/15140326.2020.1759865

Rothstein, M.A. and Coughlin, C.N. (2019) 'Ensuring compliance with quarantine by undocumented immigrants and other vulnerable groups: Public health versus politics', American Journal of Public Health, 109(9), pp. 1179-1183. Doi: 10.2105/ajph.2019.305201

Savelsberg, H. (2011) 'Sanctioning policies - Australian, American and British cross-national reflections and comparisons', Journal of Sociology \& Social Welfare, 38(3), pp. 151-174.

Schneider, D. and Harknett, K. (2020). Essential and vulnerable: Service-sector workers and paid sick leave. Available at: https://shift.hks.harvard.edu/essential-andvulnerable-service-sector-workers-and-paid-sick-leave/ (Accessed: 17 April 2020).

Small Business Administration (2020) Paycheck Protection Program. Available at: https://www.sba.gov/fundingprograms/loans/coronavirus-relief-options/paycheckprotection-program (Accessed: 20 August 2020).

Soss, J., Fording, R.C. and Schram, S.F. (2011) Disciplining the poor: Neoliberal paternalism and the persistent power of race. Chicago: University of Chicago Press.

Ståhl, C. and MacEachen, E. (2020) 'Universal Basic Income as a Policy Response to COVID-19 and Precarious Employment: Potential Impacts on Rehabilitation and Return-to-Work', Journal of Occupational Rehabilitation, online first. Doi: 10.1007/s10926-020-09923-w

Stuart, B.A. (2019) The long-run effects of recessions on education and income. IZA Institute of Labor Economics. Available at: http://ftp.iza.org/dp12426.pdf (Accessed 12 August 2020).

Sullivan, D. and von Wachter, T. (2009) 'Job displacement and mortality: An analysis using administrative data',
The Quarterly Journal of Economics, 124(3), pp. 12651306. Doi: 10.1162/qjec.2009.124.3.1265

Summers, J., Cheng, H.Y., Lin, H.H., Barnard, L.T., Kvalsvig, A., Wilson, N. and Baker, M.G. (2020) 'Potential lessons from the Taiwan and New Zealand health responses to the COVID-19 pandemic', The Lancet Regional Health-Western Pacific, 100044. Doi: 10.1016/j.lanwpc.2020.100044

Thompson, V.S. (2020) African American employment and Covid-19: Disparities and compounding risks. Available at: $\quad$ https://publichealth.wustl.edu/wpcontent/uploads/2020/04/AA-Employment-COVID-19article-by-VST-April-2020.pdf (Accessed: 12 July 2020).

U.S. Bureau of Labor Statistics (2020) Selected unemployment indicators, seasonally adjusted. Available at: https://www.bls.gov/news.release/empsit.t10.htm (Accessed: 2 September 2020).

U.S. Department of Justice (2020) Department of Justice and Department of Health and Human Services Partner to Distribute More Than Half a Million Medical Supplies Confiscated from Price Gougers. Available at: https://www.justice.gov/opa/pr/department-justice-anddepartment-health-and-human-services-partnerdistribute-more-half (Accessed: 2 September 2020).

U.S. Department of Labor (2020a) Families First Coronavirus Response Act: Employee paid leave rights. Available https://www.dol.gov/agencies/whd/pandemic/ffcraemployee-paid-leave (Accessed: 2 September 2020).

U.S. Department of Labor (2020b) Sick leave. Available at: https://www.dol.gov/general/topic/workhours/sickleave (Accessed: 2 September 2020).

U.S. Department of Labor (2020c) Unemployment insurance relief during COVID-19 outbreak. Available at: https://www.dol.gov/coronavirus/unemploymentinsurance (Accessed: 2 September 2020).

Van Parijs, P. (2013) 'The universal basic income: Why utopian thinking matters, and how sociologists can contribute to it', Politics \& Society, 41(2), pp. 171- 182. Doi: 10.1177/0032329213483106

Wang, C.J., Ng, C.Y. and Brook, R.H. (2020) 'Response to COVID-19 in Taiwan: big data analytics, new technology, and proactive testing', Jama, 323(14), pp. 1341-1342. Doi: 10.1001/jama.2020.3151

World Economic Forum (2019) The global gender gap report. Available at: http://www3.weforum.org/docs/WEF_GGGR_2020.pdf (Accessed: 13 September 2020). 